\title{
Problems with immunosuppressive agents in renal disease
}

\author{
J. S. CAMERON \\ From Guy's Hospital Medical School, London
}

'I don't know what they do to the enemy, but by God they terrify me'

Duke of Wellington, reviewing his troops.

Before looking at the many problems which may arise if immunosuppressive agents are used in renal disease, it is useful to examine briefly the place of these agents in the treatment of patients with renal problems. The general aspects of immunosuppressive drugs and their use in non-neoplastic conditions (Steinberg, Plotz, Wolff, Wong, Agus, and Decker, 1972; Lessof, 1973) have already been reviewed. One thing emerges clearly: the rationale for the use of agents of this type in patients with renal disease is ill established, the choice of agent often arbitrary and the results (if any) on the disease are often unknown. For the past five years or more, the tendency has been to use immunosuppressive agents less and less in renal disorders, hopefully retaining them in situations where their value can be, or has been, established.

There are four areas where the use of immunosuppressant drugs seem to have something to offer.

\section{Renal Transplantation}

In man, who is an outbred species, some form of immunosuppression is necessary if allografted kidneys are to survive rejection for more than a few days. Even in the situation of grafting between monozygotic twins, the use of immunosuppressants has been advocated (Glassock, Feldman, Reynolds, Dammin, and Merrill, 1968). The object of the immunosuppression is to blunt or abolish the mainly cell-mediated immune response to antigens recognized as foreign on the graft. However, antibody is certainly involved, especially in more acute forms of rejection. The original work of Murray, Calne and others over 10 years ago (Murray, Merrill, Dammin, Dealy, Alexandre, and Harrison, 1962; Starzl, 1964; Calne, 1967) in dogs and man suggested that the combination of azathioprine and prednisone might have advantages over the many other combinations of drugs tested at that time, and these drugs have

now been used on over 20000 human kidney recipients. In fact, the data upon which this conclusion were based are very scanty. We are also now aware of the great species variation in the immune response. The lack of information on alternate immunosuppressive regimes in human transplantation is distressing. Apart from the occasional use of cyclophosphamide (Starzl, Halgrimson, Penn, Martineau, Schroter, Amemiya, Putman, and Groth, 1971; Starzl, Groth, Putnam, Corman, Halgrimson, Penn, Husberg, Gustafsson, Cascardo, Geis, and Iwatsuki, 1973) and recourse to anti-lymphocyte globulin (Najarian and Simmons, 1971; Sheil, Kelly, Mears, May, Johnson, Ibels, and Stewart, 1973), azathioprine and prednisone have remained the standard immunosuppression agents, despite their obvious drawbacks, with little dissent or investigation of alternatives. Even supposing this is the best regime available, by now we should know how best to employ the drugs; in fact, practice varies from unit to unit and from time to time in an arbitrary fashion (Gleason and Murray, 1967; McGeown, 1973) following fashion rather than fact. The treatment of acute rejection with increased immunosuppression is equally arbitrary and variable (McGeown, 1973).

\section{Lupus Glomerulonephritis}

In lupus, there is evidence of increased immunological activity in the form of antibodies against cell constituents (such as DNA and RNA) and high titres of antibody against viruses, for example, rubella and EB virus. This florid expression of $B$ cell activity is now thought to result from a failure of $T$ cell function in modulating the $B$ cell response. The clinical expression of the disease, however, results from the formation of soluble complexes and their localization in tissues, so that immunosuppression in the nephritis of systemic lupus has as its goal the reduction of the immune response to endogenous and exogenous antigens. The administration of corticosteroids and immunosuppressant drugs has yet to be subjected to a long-term trial; however, the evidence from short-term trials 
(Sztejnbok, Stewart, Diamond, and Kaplan, 1971; Steinberg, Kaltreider, Staples, Goetzl, Talal, and Decker, 1971) and longer-term anecdotal comparisons (Pollak, Pirani, Dujovne, and Dillard, 1973) suggest that the survival of patients with diffuse forms of lupus nephritis has probably increased, from perhaps two to three years up to eight or 10 years from the onset of the renal disease. Various immunosuppressive agents have been used, almost always against a background of low-dosage corticosteroid treatment (15 to $30 \mathrm{mg}$ of prednisone/day or equivalent). These include mustard-like drugs, such as nitrogen mustard itself (Pollak et al, 1973), cyclophosphamide (Steinberg et al, 1971), chlorambucil (Snaith, Holt, Oliver, Dunnill, Halley, and Stephenson, 1973; Epstein and Grausz, 1974), as well as purine antagonists such as 6-mercaptopurine and azathioprine (Sztejnbok et al, 1971; Cade, Spooner, Schlein, Pickering, DeQuesada, Holcomb, Juncos, Richard, Shires, Levin, Hackett, Free, Hunt, and Fregly, 1973). In lupus, as in transplantation, prolonged administration is required, since there is evidence that the disease will 'flare' if the treatment is stopped (Sharon, Kaplan, and Diamond, 1973).

\section{Wegener's Granuloma}

This is usually associated with survival of only a few months when renal involvement is clinically visible. Renal failure is the commonest cause of death, although pulmonary insufficiency may be a problem. The condition is rare, and no controlled trials have been conducted but the anecdotal evidence is very strong that the natural history of the disease is markedly improved by treatment with either azathioprine (reviewed in Cameron, 1971; Raitt, 1971) or cyclophosphamide (Novack and Pearson, 1971) in addition to corticosteroids.

\section{Minimal-change Nephrotic Syndrome ('Lipoid Nephrosis')}

Here in contrast there is good controlled evidence that only short courses of treatment are necessary. The rationale behind the use of either corticosteroids or immunosuppressant agents is slender; the aetiology of the condition is unknown, although current debate centres on $\mathrm{T}$ cell function (Shalhoub, 1974). Usually a single brief course of corticosteroids will induce remission within at most four weeks. However, about half the patients relapse, many repeatedly. In a proportion, the side effects and dosage of corticosteroids become unacceptable, and it is for these patients that immunosuppressive agents have their place as a secondary line of treatment. Because of their known and unknown side effects, they should not be used as primary treatment of the first attack, although they may be as effective as prednisone in inducing rapid remission. Successive controlled trials (Barratt and Soothill, 1970; Barratt, Cameron, Chantler, Ogg, and Soothill, 1973; International Study of Kidney Disease in Children, 1974) have demonstrated that doses without immediate side effects, given for more than two but less than eight weeks, will induce a prolonged remission. Uncontrolled data suggest that this remission will last three years on average (Cameron, Chantler, Ogg, and White, 1974a; McDonald, Murphy, and Arneil, 1974; Chiu and Drummond, 1974; Barratt, Bercovsky, Osofsky, Soothill, and Kay, 1975). Azathioprine will also induce remission, but the patients relapse as frequently as those whose treatment is withdrawn. The majority of patients with this form of nephrotic syndrome are children so that fears for the side effects have centred particularly upon growing tissues. However, minimalchange nephrotic syndrome may be seen in adults, and, in those relapsing persistently, cyclophosphamide is at least as effective as in children in producing prolonged remission (Cameron, Turner, Ogg, Sharpstone, and Brown, 1974b).

Although there have been many papers advocating the use of immunosuppressive agents in other forms of glomerular disease, on the basis that they have an immune origin, there is no convincing evidence that any immunosuppressive drug achieves anything alone in proliferative or membranous glomerulonephritis (Cameron, 1971; Ogg and Cameron, 1973; Cameron, 1975). In fact, there are reasons for believing that these drugs are likely to accelerate the disease process and do harm (Peters and Lachmann, 1974). It is worth noting, however, that there is now the suggestion that immunosuppressant agents may be of value in some forms of glomerular disease as adjuncts to anticoagulant treatment. We have no idea whether these 'cocktails' of multiple chemotherapy do good or ill, nor do we know if the immunosuppressant agents are required as part of the mix (Brown, Wilson, Turner, Cameron, Ogg, Chantler, and Gill, 1974). The approach is being subjected to controlled trials, and if it proves fruitful will place another group of patients at risk from the hazards of chronic immunosuppression.

\section{Unwanted Effects of Immunosuppressive Drugs}

The general effects and action of immunosuppressive drugs have been reviewed on several occasions (Berenbaum, 1967; Makinodan, Santos, and Quinn, 1970; Berenbaum, 1975) and a detailed review of their actions would be out of place here; only unwanted effects will be considered in detail, and 
they may be divided for convenience into five: (1) specific effects related to individual drugs; (2) marrow depression; (3) facilitation of infection; (4) gonadal damage; (5) oncogenesis.

\section{SPECIFIC EFFECTS}

Since azathioprine and cyclophosphamide, alone or in combination with corticosteroids, have been the drugs most used in patients with renal disease, I will concentrate on these. Before examining these two drugs in detail, it is worth remembering that general pharmacology applies to these drugs as to all agents. The possibility of drug interaction exists, for example, and may contribute to toxicity. First, drugs not thought of as 'immunosuppressant' agents may inhibit immune responses, and if given coincidentally may increase the toxicity of the drug; these include sodium phenytoin (Sorrell, Forbes, Burness, and Rischbieth, 1971), antibacterial agents such as chloramphenicol, tetracycline, perhaps cotrimoxazole (Hulme and Reeves, 1971; Hall, 1974) and rifampicin (Nilsson, 1971; Dajani, Canady, Thompson, and Kasik, 1972); but the list is certainly much longer. Some agents, such as 5-fluorocytosine and cytosine arabinoside, which may be used as antifungal or antiviral agents, are inhibitors of cell division in a very similar fashion to the purine and pyrimidine analogues used for immunosuppression, and may potentiate this action. More general events may suppress the immune response, of which the most important is malnutrition (Geefhuysen, Rosen, Katz, Ipp, and Metz, 1971; World Health Organization, 1972; Mcfarlane, 1971; Faulk, 1974; Faulk, Demaeyer, and Davies, 1974), which profoundly depresses both humoral and cell-mediated immunity as well as complement. In addition, surgery (Lancet, 1974), injury (Chapel and Batchelor, 1973), uraemia (Wilson, Kirkpatrick, and Talmage, 1965; BoultonJones, Vick, Cameron, and Black, 1973) coincident viral infections, especially with EB virus (Mangi, Niederman, Kelliher, Dwyer, Evans, and Kantor, 1974), and transplantation itself (Miller, 1969) will also depress immune responses. There are also specific drug interactions which depend upon the pharmacology of the individual drug. Azathioprine is metabolized in the liver to 6-mercaptopurine and probably exerts its effect by labelling the nucleotide pool as 6-thioinosinic acid (Elion, 1972). Its inactivation involves oxidation by xanthine oxidase to thiouric acid. It is no surprise, then, that the toxicity of both 6-mercaptopurine and azathioprine should be enhanced by the xanthine oxidase inhibitor allopurinol (O'Sullivan, 1974), which also inhibits pyrimidine synthesis through the ribotides of its metabolite, oxypurinol (O'Sullivan, 1974). Uraemia itself increases the toxicity of 6-mercaptopurine, perhaps because of the altered binding of albumin in uraemia; perhaps by substrate inhibition of xanthine oxidase by the retained uric acid. Cyclophosphamide is activated in the liver by microsomal oxidative enzymes (Gershwin, Goetzl, and Steinberg, 1974), the active metabolite probably being 4-ketocyclophosphamide (Hill, Kirk, and Struck, 1970), together with many other active or partially active products. The activity of cyclophosphamide may therefore be increased by agents which induce the liver oxidative systems, such as barbiturates, corticosteroids and phenothiazines. Recently, Shapiro (1974) reported that allopurinol also increases the incidence of leucopenia when given with cyclophosphamide, as it often is in the treatment of leukaemias, lymphomas or myelomatosis. All this needs to be considered before giving an immunosuppressant agent; then, one can start worrying about individual genetic variation in handling drugs! This is particularly important for azathioprine, since a few individuals metabolize the drug much more slowly than normal and consequently suffer severe toxicity if normal doses are given.

An allegedly specific effect of azathioprine which has attracted much attention is the question of jaundice during azathioprine treatment. Both azathioprine and 6-mercaptopurine are undoubtedly hepatotoxic in mice, rats and dogs (Philips, Sternberg, Hamilton, and Clarke, 1955; Haxhe, Alexandre, and Kestens, 1967). However, evidence for such an effect in man is lacking (Ireland, Rashid, Lichtenberg, Cavallo, and Merrill, 1973); there are, of course, many other reasons, besides drug toxicity, why a patient on immunosuppression should be jaundiced; viral hepatitis (HB- and EBvirus and cytomegalovirus) severe sepsis and (most commonly) coincident administration of recognized hepatotoxic drugs. Our own experience coincides with that of Ireland et al (1973). In over 500 patients given azathioprine during a 10-year period, we have seen only one patient with what we thought to be jaundice due to this drug. This was the sole patient in whom we stopped the drug because of jaundice. In all other patients, the jaundice abated despite continuing the azathioprine. This patient resembles closely the patient reported by Llach, Friedler, Shinaberger, and Coburn (1973). In both cases, on three separate occasions liver function tests became abnormal on giving azathioprine and became normal on stopping the drug. Llach et al found a very high incidence of abnormalities of liver function tests in their transplant population, which is in contrast to our own experience. For the moment, we must seek elsewhere for an explanation of jaundice and abnormal liver function tests in patients on azathioprine, and in the great majority of patients we will 
find some other cause.

In contrast, the specific toxicity of cyclophosphamide-cystitis and alterations in bladder epitheliumis well documentated. Cyclophosphamide is metabolized in the liver, but most of these metabolites are excreted by the kidney rather than in the bile; there is thus a high concentration in the urine (Gershwin et al, 1974). In both animals and in man (Johnson and Meadows, 1971) metaplasia, telangectasia and fibrosis of the bladder may be seen with prolonged treatment using cyclophosphamide over a period of years. The usual symptoms are cystitis and dysuria, with abnormal bladder epithelial cells in the urine. Haemorrhage may be profuse, and even devastating (Hutter, Bauman, and Frank, 1969). We have seen only two out of 120 patients treated for three months or less develop symptoms, which quickly disappeared. One of our patients with systemic lupus erythematosus has had severe symptoms, with persisting bladder changes and symptoms many months following withdrawal of cyclophosphamide after treatment for five years. A further patient, a man aged 58 years with glomerulonephritis, developed a bladder carcinoma two years later after only three months on the drug and without preceding cystitis. More disturbing is the report of Worth (1971) of bladder carcinomas in two adult patients treated for two and four years for lymphoma, and the recent paper of Wall and Clausen (1975).

\section{MARROW DEPRESSION AND FACILITATION} OF INFECTION

Both cyclophosphamide and azathioprine are antiinflammatory as well as immunosuppressant agents (Arinoviche and Loewi, 1970). Cyclophosphamide affects both $B$ and $T$ cell responses in man and induces immunological tolerance readily in animals (Maguire and Maibach, 1961; Aisenberg, 1967; Dietrich and Dukor, 1968) and is more powerful than either chlorambucil or nitrogen mustard in suppressing antibody responses (Berenbaum and Brown, 1964). Azathioprine and 6-mercaptopurine do not readily induce tolerance (Schwartz and Dameshek, $1959,1963)$ and are usually considered to act mainly on mechanisms of delayed hypersensitivity; however, in combination with corticosteroids, azathioprine will greatly reduce circulating antibody levels, as will 6-mercaptopurine alone (Schwartz and Dameshek, 1959).

In larger doses, all immunosuppressive (cytotoxic) drugs will induce a generalized marrow depression, most frequently characterized by a leucopenia. During cyclophosphamide treatment this is usually preceded by a lymphopenia before the total peripheral white count falls and is readily reversible on stopping the drug. In doses of 2 to $5 \mathrm{mg} / \mathrm{kg} /$ day, it is almost never accompanied by a thrombocytopenia, although an anaemia with macrocytosis may be seen. In contrast, the leucopenia seen during azathioprine therapy is slower in onset, and may persist for days or even weeks, being apparently irreversible in an occasional patient and leading to death. Thrombocytopenia is frequently seen, may occur before or without leucopenia, and clinically evident bleeding may be a problem in transplanted patients. Anaemia may also be seen in patients on azathioprine, again with a tendency to macrocytosis. The effects of added viral or bacterial infection on the marrow must also be remembered, since some infectious agents are capable of inducing profound marrow depression in their own right. One of our patients presented with a subarachnoid haemorrhage because of thrombocytopenia induced by a septicaemia from Klebsiella.

Susceptibility to infection, however, increases long before the point of actual leucopenia is reached with either drug, because of decreased bactericidal activity in the circulating leucocytes (Berenbaum, 1967; Gershwin et al, 1974). In addition, most patients receiving immunosuppressant drugs are frequently in hospital where they may be exposed to resistant organisms, are often operated upon, and frequently given prophylactic antibiotics; all these factors will tend to increase the infection rate. The lung is a particularly vulnerable site in immunosuppressed patients (Bode, Paré, and Fraser, 1974). Finally in patients with systemic lupus, there is an increased incidence of infections even in the absence of immunosuppressive drugs or corticosteroids (Staples, Gerding, Decker, and Gordon, 1974). Whether the immunosuppression of chronic uraemia is associated with increased infection has not been established. Tuberculosis is the only specific complication that we feel sure relates to the uraemia and we have seen it reactivate and cavitate after years of quiescence in uraemic patients on several occasions.

Undoubtedly the facilitation of infection is dose related and this may account for the terrifying incidence of infections in transplant recipients, when compared with other groups of patients treated with immunosuppressant drugs at lower dosages, such as those suffering from rheumatoid arthritis and glomerulonephritis. Forty-seven percent of recipient deaths reported to the Human Kidney Transplant Registry from 1963 to 1970 were attributed primarily to infection (Simmons, Kjellstrand, and Najarian, 1972). This means that $25 \%$ of all recipients of cadaver grafts are dead within three years and infection is the main cause of death. However, one third of deaths in patients with systemic lupus erythematosus now results from sepsis rather than from renal failure (Feng, Cheah, and Lee, 1973) and the pro- 
portion in our own smaller series of 51 patients with lupus nephritis is $47 \%$ (Cameron, unpublished data).

Bacterial infections are extremely common in transplant recipients (Rifkind, Marchioro, Waddell, and Starzl, 1964; Dunea, Nakamoto, Straffon, Figueroa, Versaci, Shibagaki, and Kolff, 1965; Hill, Dahrling, Starzl, and Rifkind, 1967) and in patients with systemic lupus erythematosus (Staples et al, 1974) but not in other patients treated with immunosuppressant drugs, such as those suffering from rheumatoid arthritis or the nephrotic syndrome (Staples et al, 1974). Gram-negative organisms, particularly Pseudomonas (Massachusetts General Hospital, 1969) and Klebsiella, are common in both the transplant wound and the urinary tract, but are not usually lethal except in situations of failing graft function from rejection, when the immunosuppressive drugs may be pushed past the limits of reasonable safety. We have also lost two patients from Staphylococcus infection localizing in bone by spread through the bloodstream and this organism must not be forgotten. The total number of transplanted patients showing clinical infections with bacterial organisms is so large that more deaths occur from this cause (Rifkind et al, 1964; Hill et al, 1967) than the fungal, viral and protozoal infections discussed below which receive more publicity and interest. In this, the pattern in renal transplant recipients is the same as in recipients of liver homografts (Fulginiti, Scribner, Groth, Putnam, Brettschneider, Gilbert, Porter, and Starzl, 1968) and in marrow graft recipients (Solberg, Meuwissen, Needham, Good, and Matsen, 1971). One particular organism which has received some attention is Listeria monocytogenes. Meningitis is seen in rare patients following transplantation as in other immunosuppressed situations, but recently two patients have also been described in whom pontomedullary granulomas formed (Mahony, Tambyah, Dalton, and Wolfenden, 1974; Samuel-Gibbon, Bewick, Cameron, and Ogg, 1974) in contrast to the usually non-invasive course. Finally, $M$. tuberculosis may reactivate and disseminate under treatment with immunosuppressive drugs (Hill et al, 1967) even as long as $\mathbf{2 0}$ years following the initial infection. The reactivated cavity may then be superinfected with Aspergillus. In many renal units it is routine practice to give prophylactic antituberculous chemotherapy during immunosuppression to anyone with a history or radiological evidence of tuberculosis.

Fungal and yeast infections are again common in immunosuppressed individuals (Carbone, Sabesin, Sidransky, and Frei, 1964; Rifkind et al, 1967a; Bach et al, 1973), as in primary immuno-deficiencies of cell-mediated immunity. In our own transplantation unit, the main problem has been dissemination of gut Candida, and a number of proven local Candida and Candida septicaemias have required treatment, sometimes with success (Bewick and Raper, 1974). These have possibly become commoner over the past five years at the expense of bacterial infections; on the other hand, interest and the availability of diagnostic techniques have both increased. Candida infection of the kidney is common, and Candida has also been reported as a cause of urinary infection after transplantation (Cartwright, Shaldon, and Hall, 1972; Bewick and Raper, 1974). We have seen four patients with Aspergillus infections (Young, Bennett, Vogel, Carbone, and DeVita, 1970) but, in contrast to the experience of Bach et al (1973), this fungus has been rare compared with Candida. One of our patients who had prior Aspergillus infection died of disseminated aspergillosis despite starting amphotericin in high dosage from the start of immunosuppression. Folb and Trounce (1970) showed that cyclophosphamide, but not azathioprine and corticosteroids, given to transplant recipients would depress antibody levels against Candida, while both suppressed cell-mediated responses directed against the yeast. Other rare fungi or yeasts such as Cryptococcus neoformans (Ooi, Chen, Lim, Khoo, and Chan, 1971; Collins, Tong, Bucknall, and Warin, 1972), Nocardia asteroides and Phycomyces (Bach et al, 1973), Torulopsis glabrata and Mucor have also been recorded.

Almost any viral infection may disseminate under immunosuppression, and such infections are an important problem in both transplanted patients and patients with glomerulonephritis (Lopez, Simmons, Mauer, Najarian, Good, and Gentry, 1973, 1974). Herpes simplex (hominis) is carried by the majority of the population (Juel Jensen, 1973). Almost all immunosuppressed patients develop a 'cold sore' at some point and this may become locally erosive in immunosuppressed individuals (Montgomerie, Becroft, Croxson, Doak, and North, 1969; Juel-Jensen, 1973), causing mutilating and sometimes fatal ulceration. We have seen this in two patients, both of whom returned to countries abroad after transplantation and received excess immunosuppression without adequate supervision, to the point of leucopenia. Healing was surprisingly complete. Much more rarely, Herpes simplex viraemia with necrotizing encephalitis may ensue, which is usually fatal. Herpes zoster is carried by the majority of the population, particularly in the fifth cranial nerve ganglion, and may become disseminated in the presence of immunosuppressive agents Rifkind,. 1966), particularly corticosteroids (Cameron, 1971) Fatal chickenpox pneumonia may be seen in suppressed individuals (Scheinman and Stamler, 1969). 
Often zoster will break out after immunosuppression has begun; this is particularly common with chlorambucil (Steinberg et al, 1972), but we and others have seen it with both cyclophosphamide and azathioprine on several occasions. Cytomegalovirus is common subclinically but may cause overt disease (Kanich and Craighead, 1966; Fine, Grushkin, Malekzadeh, and Wright, 1972; Spencer and Andersen, 1970; Armstrong, Balakrishnan, and Steger, 1971), usually giving rise to liver dysfunction and jaundice (Evans, Millard, and Herbertson, 1968) but sometimes to a severe, usually lethal, pneumonia (Rifkind et al, 1967b; Coulson, Lucas, Condy, and Cohn, 1974) often in association with Pneumocystis carinii. EB virus antibody titres are often raised, and shedding of virus is twice as common in transplant recipients $(30 \%)$ as in normal individuals or uraemic subjects on dialysis (Strauch, Andrews, Siegel, and Miller, 1974).

Not only are herpes viruses facilitated by immunosuppression, the same is equally true of papovaviruses and myxoviruses. A new papovavirus (BK virus) was described in the urine of a transplant recipient by Gardner, Field, Coleman, and Hulme (1971), and the shedding of virus-laden cells may cause urinary tract obstruction in the grafted kidney or biliary obstruction in hepatic grafts (Coleman, Field, Gardner, Porter, and Starzl, 1973). Papovavirus is an aetiological agent in the rare neurological disorder progressive multifocal leucoencephalopathy, and in two transplant recipients who developed this disorder papovavirus was identified (Marz, Dinsdale, and Morrin, 1971; ZuRhein and Varakis, 1974).

Warts are common in some transplant units, up to half the patients being affected. This does not usually present a clinical problem (Spencer and Andersen, 1970) but fungating genital warts have been seen in some patients.

Death from measles pneumonia occurred in one of our children with a relapsing minimal-change nephrotic syndrome who had received an unusually intense course of cyclophosphamide (Meadow, Weller, and Archibald, 1969). This complication has also been reported in primary immunodeficient situations.

The final virus I will mention must, of course, be the bane of all renal units, that is, the virus of hepatitis $\mathrm{B}$. The propensity for uraemic patients to become carriers of hepatitis B is well known (PHLS Survey, 1974), and fortunately early identification and isolation of carriers is proving successful in limiting the spread of epidemics, such as swept through our own unit five years ago (Ogg, Bewick, Cameron, and Ellis, 1971). However, transplantation does not solve the problem, since almost all carriers retain the carrier state after transplantation, presumably as a result of the immunosuppressive drugs they receive. We transplanted 10 patients who were carriers as a result of our epidemic. Seven survived, and all are still carriers, up to six years later. Of those who died, all were still carriers when they died of other causes.

Perhaps a commoner and more important cause of death (as opposed to morbidity) in transplant recipients, and in other immunosuppressed patients, is the protozoan Pneumocystis carinii (Rifkind, Faris, and Hill, 1966; Doak, Becroft, Harris, Hitchcock, Leeming, North, Montgomerie, and Whitlock, 1973; Deteix, Mojon, Garin, Blanc, Revillard, and Traeger, 1974), the principal agent of so-called 'transplant lung'. This term should be abandoned, since it may also be seen in other patients on immunosuppression, such as those with systemic lupus erythematosus, and it is no longer thought to have an origin in an immunological response against lung tissue. The diagnosis is difficult unless needle or perbronchial lung biopsy is carried out since pneumocystis is an alveolar parasite and is not found in bronchial brushings. The clinical picture is dominated by hypoxaemia and tachypnoea, usually with a normal or near-normal radiograph, although occasionally nodular opacities may be seen (Cross and Steigbigel, 1974) particularly if cytomegalovirus infection is also present, which is often the case. There is little to hear on auscultation except fine râles. Histologically there is often infection with other agents, particularly cytomegalovirus, with occasional fungal superinfection. This emphasizes the fact that adventitious infections in immunosuppressed individuals are frequently multiple, with two, three, or even four organisms participating. It is especially true of pulmonary infections, where the Australian term 'farmyard lung' is only too appropriate in many patients (Bode et al, 1974). $X$-ray findings are not usually helpful in determining aetiology in diffuse lesions (Goodman, Davis, and Rifkind, 1967) but those which cavitate provide an obvious clinical clue. Even here, however, the cavity may contain $M$. tuberculosis, Candida and/or Aspergillus together with Gram-negative or -positive bacteria. The organisms which infect the suppressed patient are in the majority endogenous agents, usually from the gut, or from the nose, skin, or pulmonary tract. Barrier nursing, therefore, does not help in reducing the incidence of infection in these vulnerable patients unless wounds are open or drains and intravenous or other cannulae are in place.

Finally, even parasites may appear in immunosuppressed patients, such as Strongyloides stercoralis in the lung and severe scabies of the Norwegian type (Paterson, Allen, and Beveridge, 1973). 
3 GONADAL DAMAGE AND TERATOGENICITY The ability of all immunosuppressant agents to inhibit rapidly dividing cells suggests that effects will be seen upon the gut and the gonads. So far as the gut is concerned, nausea and mild gastrointestinal upsets are all that is usually seen.

Although it has been known for a long time that all alkylating agents can damage genital epithelium (Jackson, Fox, and Craig, 1961), including reports of sterility caused by cyclophosphamide in women (Fosdick, Parsons, and Hill, 1968), it was not until Fairley, Barrie, and Johnson (1972) drew attention to sterility in males with renal disease after treatment with cyclophosphamide that the frequency of this complication was widely appreciated amongst clinicians treating renal patients with the drug. This paper was rapidly followed by other reports, including confirmation that the ovary was also susceptible (Uldall, Kerr, and Tacchi, 1972; Cameron and Ogg, 1972; Qureshi, Goldsmith, Pennington, and Cox, 197?; Kumar, Biggart, McEvoy, and McGeown, 1972). All these reports concerned adults, and, taken together, suggest that cyclophosphamide, in a dose of $3 \mathrm{mg} / \mathrm{kg} /$ day or greater given for 12 weeks or longer, sterilizes adult males, usually irreversibly. The effect on the ovary appears milder, with reversible amenorrhoea the usual problem. We have now seen eight successful pregnancies in women at various times following cyclophosphamide treatment for up to 24 weeks at $3 \mathrm{mg} / \mathrm{kg} / \mathrm{day}$, and two women became pregnant while taking the drug (Cameron and Ogg, 1972). However, a later paper from Fairley and his colleagues (Warne, Fairley, Hobbs, and Martin, 1973) showed that continuous treatment for a year or more at this level of dosage led to ovarian failure in the majority (14 out of 22 ). One patient recovered ovarian function after 10 months, and three women became pregnant while on the drug. However, biopsies in six women showed ovarian fibrosis and absence of ova.

A still unanswered question is what may be the toxicity of either long courses such as these or short courses of six to eight weeks on the prepubertal gonads. This question is of great importance, since the majority of patients needing cyclophosphamide for 'minimal change' relapsing nephrotic syndrome are children. An early report (Miller, Williams, and Leissring, 1971) suggested that prolonged treatment (29 months) could lead to ovarian failure, and Hyman and Gilbert (1972) reported testicular atrophy in a boy with Hodgkin's disease who had received irradiation with gonadal shielding, as well as cyclophosphamide. We found histologically normal testes in a nephrotic child who had received three short courses of cyclophosphamide, totalling $8 \mathrm{~g}$, over 180 days ( $52 \mathrm{mg} / \mathrm{kg}$ total) (Berry, Cameron,
Ogg, Trounce, and Turner, 1972). Previously, Berry (1971) had shown no effect on subsequent reproductive performance in rats. Arneil (1972) presented further evidence from the testes and ovaries of 13 children treated for malignant disease with cyclophosphamide, suggesting no histological evidence of damage but Rapola, Koskimies, Huttunen, Floman, Vilska, and Hallman (1973) reported azoospermia in two pubertal patients who received 0.70 and 0.72 $\mathrm{g} / \mathrm{kg}$ total dose, whilst in two patients with normal testes histologically only 0.30 and $0.07 \mathrm{~g} / \mathrm{kg}$ had been given. The patients who had normal testes had also received prolonged treatment with azathioprine (four years). Penso, Lippe, Ehrlich, and Smith (1974) presented a careful follow-up study of seven patients, six of whom were given fairly prolonged (six to 19 months) courses of cyclophosphamide, when aged 11 to 18 years. Five were azoospermic, and four showed no spermatogenesis on testicular biopsy. Finally, Ettledorf (1972) and West (1972) presented data to a cyclophosphamide workshop on follow up of patients up to 10 years after treatment. These data suggest that short (four to six week) courses usually lead to normal fertility, but two patients treated 11 and 10 years previously, aged 8 and 11 , with eight weeks' cyclophosphamide $(0 \cdot 18$ and $0 \cdot 15 \mathrm{~g} / \mathrm{kg}$ ) were oligospermic, and two treated for 36 and 56 weeks were both azoospermic. Girls had generally become fertile, and four had borne normal children. I can sum up these rather confusing data as follows:

Cyclophosphamide will produce azoospermia in adult males, which is almost always irreversible, with courses of $3 \mathrm{mg} / \mathrm{kg}$ lasting 12 weeks or more.

Adult women usually experience only reversible amenorrhoea with courses of 12 to 26 weeks, but treatment for a year or longer will produce irreversible damage in the majority.

In prepubertal and pubertal males prolonged treatment undoubtedly leads to azoospermia. Courses of six weeks $(0.09 \mathrm{~g} / \mathrm{kg})$ may affect a minority, and toxicity probably appears at about eight weeks' treatment $(0 \cdot 15 \mathrm{~g} / \mathrm{kg}$ total dose).

In prepubertal and pubertal females there is no evidence as yet that courses of about $0 \cdot 15 \mathrm{~g} / \mathrm{kg}$ total dose affect the ovary. Prolonged treatment, however, will lead to ovarian failure, as in adults.

What of azathioprine? So far, there has been no suggestion that this drug affects the gonads in a similar fashion to cyclophosphamide. A number of patients with systemic lupus erythematosus (including two of our own), and probably over 50 female transplant recipients (including two of our own) have had babies successfully whilst taking azathioprine and steroids-often for several years (Golby, 1970; Penn, Makowski, Droegmuelle, Halgrimson, and 
Starzl, 1971 ; Coté, Meuwissen, and Pickering, 1974; Nolan, Sweet, Laros, and Roure, 1974) but one such child with chromosome abnormalities has been reported (Leb, Weisskopf, and Kanovitz, 1971), and in view of the obvious teratogenic potential of azathioprine (Thiersch, 1962; Githens, Rosenkrantz, and Tunnock, 1965) it would be foolish to assume that azathioprine is innocuous during pregnancy. A meningoymyelocele has also been noted in the child of a male patient following transplantation (Tallent, Simmons, and Najarian, 1970), and an internal hydrocephalus in the child of one of the two male transplant recipients who have fathered children in our unit, as in the animal work of Githens et al (1965). In addition, the children born of mothers taking azathioprine and corticosteroids may be temporarily immunodeficient (Coté et al, 1974).

There is also good evidence (Greenberg and Tanaka, 1964; Toledo, Harper, and Moser, 1971; White, R.H.R., personal communication) that cyclophosphamide is teratogenic in humans. Although normal children have been born after cyclophosphamide treatment during pregnancy (Coats, 1970; Hardin, 1972), the possiblity of leuka $\in$ mogenesis remains, as it does for children born to women previously on cyclophosphamide.

\section{ONCOGENESIS}

We must now consider the most difficult and most important problem; the possibility that immunosuppressant agents may be oncogenic. This is a risk which, at the moment, is impossible to assess adequately, because tumours may appear only after a long latent period.

Thomas (1959) and later Burnet (1967) developed the idea that immunological surveillance was an important mechanism in the detection and destruction of abnormal cells and therefore the prevention of malignancy (Fahey, 1971; Schwartz, 1972; British Medical Journal, 1972). Swanson and Schwartz (1967) predicted that immunosuppression would lead to an increased incidence of malignancy. This prediction has been amply and terribly fulfilled for transplant recipients (Penn, 1970; Hoover and Fraumeni, 1973), in whom the incidence of lymphomas is up to 300 times the control incidence. The peculiarly high incidence of intracerebral lymphoid tumours has been much discussed (Schneck and Penn, 1971; Lancet, 1971). Skin tumours have also a greatly increased incidence in Australia (Walder, Robertson, and Jeremy, 1971). Although Hoover and Fraumeni (1973) found an increased incidence of non-lymphoid tumours in transplant recipients, this is not yet evident in the data collected from units in the United Kingdom (Kinlen and Doll, unpublished).
Possible mechanisms for the increased incidence of lymphoid tumours, and possibly other neoplasma, are still debated. Direct damage to genetic material has been recorded with both azathioprine (Jensen, 1970) and cyclophosphamide. Reduction of immune surveillance, as suggested by Swanson and Schwartz (1967), is perhaps the mechanism most favoured, but facilitation of oncogenic viruses or virally transformed cells is an alternative (and to some extent coincident) possibility (Allison, 1970; Sehwartz, 1972). EB virus is known to be associated with Burkitt's lymphoma and nasopharyngeal carcinoma, and Doak, Montgomerie, North, and Smith (1968) reported reticulum cell sarcomas in association with extensive herpes hominis infection. Finally, the presence of the foreign antigen load in the form of an organ transplant must not be forgotten, and the possibility of transfer of lymphoid cells from donor to recipient borne in mind (Smithers and Field, 1969).

If either of those last two suggestions is important, then one might expect that in immunosuppressed situations other than transplantation there would not be an increased incidence of tumours. The data on this point are, as yet, incomplete. One problem lies in the fact that at least one of the diseases treated, lupus erythematosus, already carries a higher incidence of tumours than normal (Andreev and Zlatkov, 1968). This is also true of the animal model, the NZB/NZW mouse, and treatment with both azathioprine (Casey, 1973) and cyclophosphamide (Walker and Bole, 1973) increases the incidence of tumours to almost $100 \%$ of animals. However, in human lupus treated with azathioprine there are, as yet, only three reports of tumour development (Lipsmeyer, 1972; McAdam, Paulus, and Peter, 1974; Klein, Pereira, and Kantor, 1974), together with one lymphosarcoma in a patient treated with cyclophosphamide (Tannenbaum and Schur, 1974).

In patients with glomerulonephritis and rheumatic disorders, however, there are several reports of tumours in patients treated with both azathioprine (Sharpstone, Ogg, and Cameron, 1969; Patterson, Norton, and Schwartz, 1971; Fusco, Mattioli, and Berocchi, 1971; Aptekar, Steinberg, and Decker, 1973 and cyclophosphamide (Fosdick, Parsons, and Hill, 1969; Worth, 1971; Bashour, Mancer, and Rance, 1973; Cameron et al, 1974a, b). Obviously these reports must be set against the expected incidence of the various tumours in the populations at risk. This can only be done prospectively, and a survey involving both transplanted and non-transplanted patients who received at least three months' immunosuppression has been in progress for over two years under the direction of Dr L. J. Kinlen and Professor Sir R. Doll of Oxford. To date, although 
the numbers are small, there appears to be an increased incidence of lymphoid tumours in immunosuppressed patients with azathioprine who have not received transplants but the number of nonlymphoid tumours does not exceed expectations (Kinlen, personal communication). The fact that transplantation, followed by prolonged immunosuppression can be done successfully in patients already bearing carcinomata without dissemination (Evans and Calne, 1974), does not suggest that a surveillance mechanism widely important in the elimination of malignant cells is being suppressed. On the other hand, transplanted cancers are rejected on stopping immunosuppression.

In view of the long latent period between the events and the maximum incidence of neoplasia in other situations, such as leukaemia in survivors following the Hiroshima atomic bomb explosion, or following irradiation of patients with ankylosing spondylitis, we may have to wait a decade or more before the cost and benefit of treatment with immunosuppressive agents can be assessed in full. However, at least the lymphoid tumours seem to have their maximum incidence at one to two years after transplantation.

Finally, we must consider the possible development of immunosuppressive regimes even more complex than those in use at present, with side effects which may be even more difficult to evaluate or predict. The use of triple or quadruple chemotherapy in the treatment of neoplasia has been exploited for some time (DeVita and Schein, 1973). Recently, the idea of using more than two immunosuppressant drugs in low dosage to minimize the short-term side effects has been explored in renal disease. Gelfand, Steinberg, Nagle, and Knepshield (1972) showed that a triple regime of corticosteroids, cyclophosphamide and azathioprine was more effective in suppressing the renal disease of NZB/NZW mice than any single drug or double combination. Friedman, Ueno, Beyer, and Nicastri (1973) demonstrated better renal allograft survival in rabbits than with double or single drug therapy, using the same triple regime. To date little use has been made in man, although Mukherjee (1971) presented a preliminary report on the use of triple chemotherapy in proliferative glomerulonephritis. We have also used this approach in a small number of patients with systemic lupus erythematosus (Cameron, Vosnides, Turner, Ogg, Lessof, Chantler, and Brown, 1975). What is quite certain is that whatever the shortterm benefits, if any, of these complex regimes, the long-term effects will need very careful evaluation.

I should like to thank Mr M. Bewick for his assistance in preparing this manuscript.
References

Aisenberg, A. C. (1967). Studies on cyclophosphamide-induced tolerance to sheep erythrocytes. J. exp. Med., 125, 833-845

Allison, A. C. (1970). Potentiation of viral carcinogenesis by immunosuppression. Brit. med. J., 4, 419-420.

Andreev, V. C., and Zlatkov, N. B. (1968). Systemic lupus erythematosus and neoplasia of the lymphoreticular system. Brit. $J$. Derm., 80, 503-508.

Aptekar, R. G., Steinberg, A. D., and Decker, J. L. (1973). Complications of cytotoxic agents in systemic lupus erythematosus and rheumatoid arthritis. (Quoted in Tannenbaum and Schur, 1974).

Arinoviche, R., and Loewi, G. (1970). Comparison of the effects of two cytotoxic drugs and of antilymphocytic serum on immune and non-immune inflammation in experimental animals. Ann. rheum. Dis., 29, 32-39.

Armstrong, B., Balakrishnan, S. L., and Steger, L. (1971). Cytomegalovirus infections with viraemia following renal transplantation. Arch. intern. Med., 127, 111-115.

Arneil, G. C. (1972). Cyclophosphamide and prepubertal testis. (Letter). Lancet, 2, 1259-1260.

Bach, M. C., Sahyoun, A., Adler, J. L., Schlesinger, R. M., Breman, J., Madras, P., P'Eng, F.-K., and Monaco, R. P. (1973). Influence of rejection therapy on fungal and nocardial infections in renal-transplant recipients. Lancet, 1, 180-184.

Barratt, T. M., Bercovsky, A., Osofsky, S. G., Soothill, J. F., and Kay, R. (1975). Cyclophosphamide treatment in steroidsensitive nephrotic syndrome of childhood. Lancet, 1, 55-58.

Barratt, T. M., Cameron, J. S., Chantler, C., Ogg, C. S., and Soothill, J. F. (1973). Comparative trial of two weeks and eight weeks cyclophosphamide in steroid-sensitive relapsing nephrotic syndrome of childhood. Arch. Dis. Childh., 48, 286-290.

Barratt, T. M., and Soothill, J. F. (1970). Controlled trial of cyclophosphamide in steroid-sensitive, relapsing nephrotic syndrome of childhood. Lancet, 2, 479-482.

Bashour, B. N., Mancer, K., and Rance, C. P. (1973). Malignant mixed Mullerian tumour of the cervix following cyclophosphamide therapy for nephrotic syndrome. J. Pediat., 82, 292-293.

Berenbaum, M. C. (1965). Immunosuppressive agents. Brit. med. Bull., 21, 140-146.

Berenbaum, M. C. (1967). Immunosuppressive agents and allogenic transplantation. J. clin. Path., 20 (supplement), 471-498.

Berenbaum, M. C. (1975). The clinical pharmacology of immunosuppressive agents. In Clinical Aspects of Immunology, edited by P. G. H. Gell, R. R. A. Coombs, and P. J. Lachmann, pp. 689-758. Blackwells, Oxford.

Berenbaum, M. C., and Brown, I. N. (1964). Dose-response relationships for agents inhibiting the immune response. Immunology, 7. 65-71.

Berry, C. L. (1971). Cyclophosphamide therapy in prepubertal rats and subsequent reproductive performance. Arch. Dis. Childh., 46, 709-711.

Berry, C. L., Cameron, J. S., Ogg, C. S., Trounce, D. Q., and Turner, D. R. (1972). Cyclophosphamide and the prepubertal testis. Lancet, 2, 1033-1034.

Bewick, M., and Raper, D. A. (1974). The diagnosis of systemic fungal infection in renal transplant patients and treatment with clotrimazole. Postgrad. med. J., July supplement, 34-38.

Bode, F. R., Paré, J. A. P., and Fraser, R. G. (1974). Pulmonary diseases in the compromised host. Medicine (Baltimore), 53, 255-293.

Boulton-Jones, M., Vick, R. M., Cameron, J. S., and Black, P. J. (1973). Immune responses in uremia. Clin. Nephrol., 1, 351-360

British Medical Journal (1972). Editorial. Immunosuppression and malignancy. 3, 713-714.

Brown, C. B., Wilson, D., Turner, D., Cameron, J. S., Ogg, C. S. Chantler, C., and Gill, D. (1974). Combined immunosuppression and anticoagulation in rapidly progressive glomerulonephritis. Lancet, 2, 1166-1172.

Burnet, F. M. (1967). Immunological aspects of malignant disease. Lancet, 1, 1171-1174.

Cade, R., Spooner, G., Schlein, E., Pickering, M., DeQuesada, A., Holcomb, A., Juncos, L., Richard, G., Shires, D., Levin, D., Hackett, R., Free, J., Hunt, R., and Fregly, M. (1973). Comparison of azathioprine, prednisone, and heparin alone or combined in treating lupus nephritis. Nephron, 10, 37-56.

Calne, R. Y. (1967). Renal Transplantation, 2nd ed., Arnold, Bristol.

Cameron, J. S. (1971). Immunosuppressant agents in the treatment of glomerulonephritis. J. roy. Coll. Phycns Lond., 5, 301-322. 
Cameron, J. S. (1975). The treatment of glomerulonephritis. In Kidney, edited by S. A. Papper. National Kidney Foundation, Washington, D.C.

Cameron, J. S., Chantler, C., Ogg, C. S., and White, R. H. R. (1974a). Long-term stability of remission in nephrotic syndrome after treatment with cyclophosphamide. Brit. med. J., 4, 7-11.

Cameron, J. S., and Ogg, C. S. (1972). Sterility and cyclophosphamide. (Letter). Lancet, 1, 1174-1175.

Cameron, J. S.. Turner, D. R., Ogg, C. S., Sharpstone, P., and Brown, C. B. (1974b). The nephrotic syndrome in adults with "minimal change" glomerular lesions. Quart. J. Med., 43, 461-488.

Cameron, J. S., Vosnides, G., Turner, D. R., Ogg, C. S., Lessof, M. Chantler, C., and Brown, C. B. (1975). Renal involvement in collagen diseases. In Renal Involvement in Systemic disorders, edited by A. J. Eisinger. (In press).

Carbone, P. P., Sabesin, S. M., Sidransky, H., and Frei, E. (1964). Secondary aspergillosis. Ann. intern. Med., 60, 556-567.

Cartwright, R. Y., Shaldon, C., and Hall, G. H. (1972). Urinary candidiasis after renal transplantation. (Letter). Brit. med. J., 2, 351.

Casey, T. P. (1973). Azathioprine administration to NZB X NZW hybrid mice with lupus nephritis: beneficial effect complicated by development of malignant lymphomas. N.Z. med. J., 78, 290-295.

Chapel, H. M., and Batchelor, J. R. (1973). Rosette inhibition test in severely burned patients. Brit. med. J., 4, 385-388.

Chiu, J., and Drummond, K. N. (1974). Long-term follow up of cyclophosphamide therapy in frequent relapsing minimal lesion nephrotic syndrome. J. Pediat., 84, 825-830.

Coats, A. (1970). Cyclophosphamide in pregnancy. Aust. N. Z. J. Obstet. Gynaec., 10, 33-34.

Coleman, D. V., Field, A. M., Gardner, S. D., Porter, K. A., and Starzl, T. E. (1973). Virus-induced obstruction of the ureteric and cystic duct in allograft recipients. Transplant. Proc., 5, 9598.

Collins, J. V., Tong, D., Bucknall, R. G., and Warin, A. P. (1972). Cryptococcal meningitis as a complication of systemic lupus erythematosus treated with systemic corticosteroids. Postgrad. med. J., 48, 52-55.

Coté, C. J., Meuwissen, H. J., and Pickering, R. J. (1974). Effects on the neonate of prednisone and azathioprine administered to the mother during pregnancy. J. Pediat., 85, 324-328.

Coulson, A. S., Lucas, Z. J., Condy, M., and Cohn, R. (1974). An epidemic of cytomegalovirus disease in a renal transplant population. West. J. med., 120, 1-7.

Cross, A. S., and Steigbigel, R. T. (1974). Pneumocystis carinii pneumonia presenting as localized nodular densities. New Engl. J. Med., 291, 831-832.

Dajani, B. M., Canady, M. S., Thompson, J. S., and Kasik, J. E. (1972). Rifampicin: an immunosuppressant? Lancet, 2, 1094.

Deteix, P., Mojon, M., Garin, J. P., Blanc, N., Revillard, J. P., and Traeger, J. (1974). Pneumopathies à pneumocystis carinii après transplantation rénale. Lyon Med., 232, 37-47.

DeVita, V. T., and Schein, P. S. (1973). The use of drugs in combination for the treatment of cancer. New Engl. J. Med., 288, 9981006.

Dietrich, F. M., and Dukor, P. (1968). The immune response to heterologous red cells in mice. IV. Induction of unresponsiveness to weakly immunogenic red cells by cyclophosphamide and cortisone acetate. Clin. exp. Immunol., 3, 783-793.

Doak, P. B., Becroft, D. M. O., Harris, E. A., Hitchcock, G. C., Leeming, B. W. A., North, J. D. K., Montgomerie, J. Z., and Whitlock, R. M. L. (1973). Pneumocystis carinii pneumoniatransplant lung. Quart. J. Med., 42, 59-71.

Doak, P. B., .Montgomerie, J. Z., North, J. D. K., and Smith, F. (1968). Reticulum cell sarcoma after renal homotransplantation and azathioprine and prednisone therapy. Brit. med. J., 4, 746-748.

Dunea, G., Nakamoto, S., Straffon, R. A., Figueroa, J. E., Versaci, A. A., Shibagaki, M., and Kolff, W. J. (1965). Renal homotransplantation in twenty-four patients. Brit. med. J., 1, 7-13.

Elion, G. B. (1972). Significance of azathioprine metabolites. Proc. roy. Soc. Med., 65, 257-259.

Epstein, W. V., and Grausz, H. (1974). Favourable outcome in diffuse proliferative glomerulonephritis of systemic lupus erythematosus. Arthr. and Rheum., 17, 129-142.

Ettledorf, J. N. (1972). Cyclophosphamide in renal disease. Presented to the International Workshop on Immunosuppressive Therapy "Risk Benefit Assessment". Hotel Americana, New
York, June, 1972.

Evans, D. B., and Calne, R. Y. (1974). Renal transplantation in patients with carcinoma. Brit. med. J., 4, 134-136.

Evans, D. B., Millard, P. R., and Herbertson, B. M. (1968). Hepatic dysfunction associated with renal transplantation. Lancet, 2, 929-934.

Fahey, J. L. (1971). Cancer in the immunosuppressed patient. Ann. intern. Med., 75, 310-312.

Fairley, K. F., Barrie, J. U., and Johnson, W. (1972). Sterility and testicular atrophy related to cyclophosphamide therapy. Lancet, 1 , 568-569.

Faulk, W. P. (1974). Nutrition and immunity. Nature (Lond.), 250, 283-284.

Faulk, W. P., Demaeyer, E. M., and Davies, A. J. S. (1974). Some effects of malnutrition on the immune response in man. Amer. J. clin. Nutr., 27, 638-646.

Feng, P. H., Cheah, P. S., and Lee, Y. K. (1973). Mortality in systemic lupus erythematosus : a 10 year review. Brit. med. J., 4, 772-774.

Fine, R. N., Grushkin, C. M., Malekzadeh, M., and Wright, H. T., Jr. (1972). Cytomegalovirus syndrome following renal transplantation. Arch. Surg., 105, 564-570.

Folb, P. J., and Trounce, J. R. (1970). Immunological aspects of candida infection complicating steroid and immunosuppressive drug therapy. Lancet, 2, 1112-1114.

Fosdick, W. M., Parsons, J. L., and Hill, D. F. (1968). Long-term cyclophosphamide therapy in rheumatoid arthritis. Arthr. and Rheum., 11, 151-161.

Fosdick, W. M., Parsons, J. L., and Hill, D. F. (1969). Long-term cyclophosphamide (CP) therapy in rheumatoid arthritis: a progress report, six years' experience.(Abstr.) Arthr. and Rheum., $12,663$.

Friedman, V. A., Ueno, A., Beyer, M. M., and Nicastri, A. D. (1973). Combination drug treatment in immunosuppression: effect of azathioprine, cyclophosphamide, and methylprednisolone on rabbit renal allografts. Transplantation, 15, 619-623.

Fulgitini, V. A., Scribner, R., Groth, C. G., Putnam, C. W., Brettschneider, L., Gilbert, S., Porter, K. A., and Starzl, T. E. (1968). Infections in recipients of liver homografts. New Engl. J. Med., 279, 619-626.

Fusco, F. A., Mattioli, F., and Berocchi, I. (1971). Quoted by McEwan, A., and Petty, L. G. (1972). Oncogenicity of immunosuppressive drugs. Lancet, 1, 326-327.

Gardner, S. D., Field, A. M., Coleman, D. V., and Hulme, B. (1971) New human papovavirus (B.K.) isolated from urine after renal transplantation. Lancet, 1, 1253-1256.

Geef huysen, J., Rosen, E. U., Katz, J., Ipp, T., and Metz, J. (1971) Impaired cellular immunity in Kwashiorkor with improvement after therapy. Brit. med. J., 4, 527-529.

Gelfand, M. C., Steinberg, A. D., Nagle, R., and Knepshield, J. H. (1972). Therapeutic studies in NZB/W mice. I: synergy of azathioprine, cyclophosphamide and methylprednisolone in combination. Arthr. and Rheum., 15, 239-246.

Gershwin, M. E., Goetzl, E. J., and Steinberg, A. D. (1974). Cyclophosphamide: use in practice. Ann. intern. Med., 80, 531-540.

Githens, J. H., Rosenkrantz, J. G., and Tunnock, S. M. (1965). Teratogenic effects of azathioprine (imuran). J. Pediat., 66, 959-961.

Glassock, R. J., Feldman, D., Reynolds, E. S., Dammin, G. J., and Merrill, J. P. (1968). Human renal isografts: a clinical and pathologic analysis. Medicine (Baltimore), 47, 411-454.

Gleason, R. E., and Murray, J. E. (1967). Report from Kidney Transplant Registry: Analysis of variables in the function of human kidney transplants. II. Immunosuppressive regimes. Transplantation, 5, 360-373.

Golby, M. (1970). Fertility after renal transplantation. Transplantation, 10, 201-204.

Goodman, N., Davis, M. L., and Rifkind, D. (1967). Pulmonary roentgen findings following renal transplantations. Radiology, $89,621-625$.

Greenberg, L. H., and Tanaka, K. R. (1964). Congenital anomalies probably produced by cyclophosphamide. J. Amer. med. Ass., 188, 423-425.

Hall, C. L. (1974). Co-trimoxazole and azathioprine: a safe combination. Brit. med. J., 4, 15-16.

Hardin, J. A. (1972). Cyclophosphamide treatment of lymphoma during the third trimester of pregnancy. Obstet. and Gynec., 39, 850-851.

Haxhe, J. J., Alexandre, G. P. J., and Kestens, P. J. (1967). The effect of imuran and azaserine on liver function tests in the dog. Arch. 
intern. Pharmacodyn. Ther., 168, 366-372.

Hill, D. L., Kirk, M. C., and Struck, R. F. (1970). Isolation and identification of 4-ketocyclophosphamide, a possible active form of the antitumour agent cyclophosphamide. J. Amer. chem. Soc., 92, 3207-3208.

Hill, R. B., Jr., Dahrling, B. E., II, Starzl, T. E., and Rif kind, D. (1967), Death after transplantation: an analysis of 60 cases. Amer. J. Med., 42, 327-334.

Hoover, R., and Fraumeni, J. F., Jr. (1973). Risk of cancer in renal transplant recipients. Lancet, 2, 55-57.

Hulme, B., and Reeves, D. S. (1971). Leucopenia associated with trimethoprim-sulphamethoxazole after renal transplantation. Brit. med. J., 3, 610-612.

Hutter, A. M., Jr., Bauman, A. W., and Frank, I. N. (1969). Cyclophosphamide and severe hemorrhagic cystitis. N. Y. St. Med. J., 69, 305.

Hyman, L. R., and Gilbert, E. F. (1972). Testicular atrophy in a prepubescent male after cyclophosphamide therapy. (Letter). Lancet, 2, 426-427.

International Study of Kidney Disease in Children (1974). Report. Prospective, controlled trial of cyclophosphamide therapy in children with the nephrotic syndrome. Lancet, 2, 423-427.

Ireland, P., Rashid, A., Lichtenberg, L. V., Cavallo, T., and Merrill, J. P. (1973). Liver disease in kidney transplant patients receiving azathioprine. Arch. intern. Med., 132, 29-37.

Jackson, H., Fox, B. W., and Craig, A. W. (1961). Antifertility substances and their assessment in the male rodent. $J$. Reprod. Fertil., 2, 447-465.

Jensen, M. K. (1970). Effect of azathioprine on the chromosome complement of human bone marrow cells. Int. J. Cancer, 5, 147-151.

Johnson, W. W., and Meadows, D. C. (1971). Urinary bladder fibrosis and telangectasia associated with long term cyclophosphamide therapy. New Engl. J. Med., 284, 290-294.

Juel-Jensen, B. E. (1973). Herpes simplex and zoster. Brit. med. J., 1, 406-410.

Kanich, R. E., and Craighead, J. E. (1966). Cytomegalovirus infection and cytomegalic inclusion disease in renal homotransplant recipients. Amer. J. Med., 40, 874-882.

Klein, M. B., Pereira, F. A., and Kantor, I. (1974). Kaposi sarcoma complicating systemic lupus erythematosus treated with immunosuppression. Arch. Derm., 110, 602-604.

Kumar, R., Biggart, J. D., McEvoy, J., and McGeown, M. G. (1972). Cyclophosphamide and reproductive function. Lancet, 1, 1212 1214.

Lancet (1971). Editorial. Immunosuppression and intracerebral lymphomas. Lancet, 2, 143-144.

Lancet (1974). Editorial. Postoperative immunosuppression. Lancet, 2, 817-818.

Leb, D. E., Weisskopf, B., and Kanovitz, B. S. (1971). Chromosome aberrations in the child of a kidney transplant recipient. Arch. intern. Med., 128, 441-444.

Lessof, M. H. (1973). Immunosuppressives for non-malignant conditions. Brit. J. hosp. Med., 10, 181-188.

Lipsmeyer, E. A. (1972). Development of malignant cerebral lymphoma in a patient with systemic lupus erythematosus treated with immunosuppression. Arthr. and Rheum., 15, 183-186.

Llach, F., Friedler, R. M., Shinaberger, J. H., and Coburn, J. W. (1973). Liver abnormalities in renal transplant recipients. Proc. Dial. Transplant. Forum, 2, 190-195.

Lopez, C., Simmons, R. L., Mauer, S. M., Najarian, J. S., Good, R. A., and Gentry, S. (1974). Assessment of renal allograft rejection with virus infections. Amer. J. Med., 56, 280-289.

Lopez, C., Simmons, R. L., Mauer, M., Park, B., Najarian, J. S., and Good, R. A. (1973). Role of virus infections in immunosuppressed renal transplant patients. Transplant. Proc., 5, 803-806.

McAdam, L., Paulus, H. E., and Peter, J. B. (1974). Adenocarcinoma of the lung during azathioprine therapy. Arthr. and Rheum., 17, 92-94.

McDonald, J., Murphy, A., and Arneil, G. C. (1974). Long-term assessment of cyclophosphamide for nephrosis in children. Lancet, 2, 980-982.

McFarlane, H. (1971). Cell-mediated immunity in protein calorie malnutrition. (Letter). Lancet, 2, 1146-1147.

McGeown, M. G. (1973). Immunosuppression for kidney transplantation. Lancet, 2, 310-312.

Maguire, H. C., Jr., and Maibach, H. I. (1961). Specific immune tolerance to anaphylactic sensitization (egg albumen) induced in the guinea pig by cyclophosphamide (cytoxan). J. Allergy, 32, 406408 .
Mahony, J. F., Tambyah, J. A., Dalton, V. C., and Wolfenden, W. H. (1974). Pontomedullary listeriosis in renal allograft recipients. Brit. med. J., 2, 705.

Makinodan, T., Santos, G. W., and Quinn, R. P. (1970). Immunosuppressive drugs. Pharmacol. Rev., 22, 189-247.

Mangi, R. J., Niederman, J. C., Kelliher, J. E., Jr., Dwyer, J. M., Evans, A. S., and Kantor, F. S. (1974). Depression of cellmediated immunity during acute infectious mononucleosis. New Engl. J. Med., 291, $1149-1153$.

Manz, K. J., Dinsdale, H. B., and Morrin, P. A. F. (1971). Progressive multifocal leukoencephalopathy after renal transplantation: demonstration of papova-like virions. Ann. intern. Med., 75, 7781 .

Massachussetts General Hospital (1969). Case Records-case 45-1969. New Engl. J. Med., 281, 1059-1069.

Meadow, S. R., Weller, R. O., and Archibald, R. W. R. (1969). Fatal systemic measles in a child receiving cyclophosphamide for nephrotic syndrome. Lancet, 2, 876-878.

Miller, J. (1969). Antibody production in recipients of allografts. (Letter). Lancet, 2, 1251.

Miller, J. J., Williams, G. F., and Leissring, J. C. (1971). Multiple late complications of therapy with cyclophosphamide, including ovarian destruction. Amer. J. Med., 50, 530-535.

Montgomerie, J. Z., Becroft, D. M. O., Croxson, M. C., Doak, P. B., and North, J. D. K. (1969). Herpes-simplex-virus infection after renal transplantation. Lancet, 2, 867-871.

Mukherjee, A. P. (1971). Combined prednisolone, azathioprine and cyclophosphamide treatment for persistent proliferative glomerulonephritis in adults. Lancet, 2, 1350-1353.

Murray, J. E., Merrill, J. P., Dammin, G. J., Dealy, J. B., Jr., Alexandre, G. W., and Harrison, J. H. (1962). Kidney transplantation in modified recipients. Ann. Surg., 156, 337-355.

Najarian, J. S., and Simmons, R. L. (1971). The clinical use of antilymphocyte globulin. New Engl. J. Med., 285, 158-166.

Nilsson, B. S. (1971). Rifampicin: An immunosuppressant? Lancet, 2 , 374.

Nolan, G. H., Sweet, R. L., Laros, R. K., and Roure, C. A. (1974). Renal cadaver transplantation followed by successful pregnancies. Obstet. and Gynec., 43, 732-739.

Novack, S. N., and Pearson, C. M. (1971). Cyclophosphamide therapy of Wegener's granulomatosis. New Engl. J. Med., 284, 938-942.

Ogg, C. S., Bewick, M., Cameron, J. S., and Ellis, F. G. (1972). Hepatitis at Guy's Hospital. Proc. europ. Dial. Transplant. Ass., 9, 228-234.

Ogg, C. S., and Cameron, J. S. (1973). Cyclophosphamide and the treatment of the nephrotic syndrome in adults. Amer. Heart.J., 86, 577-581.

Ooi, B. S., Chen, B. T. M., Lim, C. H., Khoo, O. T., and Chan, K. T. (1971). Survival of a patient transplanted with a kidney infected with cryptococcus neoformans. Transplantation, 11, 428429.

O'Sullivan, W. J. (1974). Metabolic side effects of allopurinol. Progr. Biochem. Pharmacol., 9, 174-193.

Paterson, W. D., Allen, B. R., and Beveridge, G. W. (1973). Norwegian scabies during immunosuppressive therapy. Brit. med. J., 4, 211-212.

Patterson, J. F., Norton, R. A., and Schwartz, R. S. (1971). Azathioprine treatment of ulcerative colitis, granulomatous colitis and regional enteritis. Amer. J. dig. Dis., 16, 327-332.

Penn, I. (1970). Malignant tumours in organ transplant recipients. Recent Results Cancer Res., 35.

Penn, I., Makowski, E., Droegmuelle, W., Halgrimson, C. G., and Starzl, T. E. (1971). Parenthood in renal homograft recipients $J$. Amer, med. Ass, 216, 1755-1761.

Penso, J., Lippe, B., Ehrlich, R., and Smith, F. G., Jr. (1974). Testicular function in prepubertal and pubertal male patients treated with cyclophosphamide for nephrotic syndrome. J. Pediat., 84, 831836.

Peters, D. K., and Lachmann, P. J. (1974). Immunity deficiency in pathogenesis of glomerulonephritis. Lancet, 1, 58-60.

Philips, F. S., Sternberg S. S., Hamilton, L., and Clarke, D. A. (1955). The toxic effect of 6-mercaptopurine and related compounds. Ann. N. Y. Acad. Sci., 60, 283-296.

Pollak, V. E., Pirani, C. L., Dujovne I., and Dillard, M. G. (1973) The clinical course of lupus nephritis: relationship to the renal histologic findings. In Glomerulonephritis, edited by $\mathbf{P}$. Kincaid-Smith, T. H. Mathew, E. L. Becker, vol. II, pp. $1167-$ 1181. Wiley, New York.

Public Health Laboratory Service Survey (1974). Decrease in the 
incidence of hepatitis in dialysis units associated with prevention programme. Brit. med. J., 4, 751-754.

Qureshi, M. S. A., Goldsmith, H. J., Pennington, J. H., and Cox, P. E. (1972). Cyclophosphamide therapy and sterility. Lancet,. 2, 1290-1291.

Raitt, J. W. (1971). Wegener's granulomatosis: treatment with cytotoxic agents and adrenocorticoids. Ann. intern. Med., 74, 344356.

Rapola, J., Koskimies, O., Huttunen, N. P., Floman, P., Vilska, J., and Hallman, N. (1973). Cyclophosphamide and the pubertal testis. (Letter). Lancet, 1, 98-99.

Rif kind, D. (1966). The activation of varicella-zoster virus infections by immunosuppressive therapy. J. Lab. clin. Med., 68, 463-474.

Rifkind, D., Faris, T. D., and Hill, R. B., Jr. (1966). Pneumocystis carinii pneumonia. Studies on the diagnosis and treatment. Ann. intern. Med., 65, 943-956.

Rif kind, D., Goodman, N., and Hill, R. B., Jr. (1967a). The clinical significance of cytomegalovirus infection in renal transplant recipients. Ann. intern. Med., 66, 1116-1117.

Rifkind, D., Marchioro, T. L., Schneck, S. A., and Hill, R. B., Jr. (1967b). Systemic fungal infections complicating renal transplantation and immunosuppressive therapy. Clinical microbiologic, neurologic and pathologic features. Amer. J. Med., 43, 28-38.

Rifkind, D., Marchioro, T. L., Waddell, W. R., and Starz], T. E. (1964). Infectious diseases associated with renal homotransplantation. I. Incidence, types and predisposing factors. II. Differential diagnosis and management. J. Amer. med. Ass., 189, 397-407.

Samuel-Gibbon, A., Bewick, M., Cameron, J. S., and Ogg, C. S. (1974). Listeria monocytogenes infection in a renal transplant recipient. Guy's Hosp. Rep., 122, 205-210.

Scheinman, J. I., and Stamler, F. W. (1968). Cyclophosphamide and fatal varicella. J. Pediat., 74, 117-119.

Schneck, S. A., and Penn, I. (1971). De novo brain tumours in renal transplant recipients. Lancet, 1, 983-986.

Schwartz, R. S. (1972). Immunoregulation, oncogenic viruses and malignant lymphomas. Lancet, 1, 1266-1269.

Schwartz, R. S., and Dameshek, W. (1959). Drug-induced immunological tolerance. Nature (Lond.), 183, 1682-1683.

Schwartz, R. S., and Dameshek, W. (1963). The role of antigen dosage in drug-induced immunologic tolerance. J. Immunol., 90, 703710.

Shalhoub, R. J. (1974). Pathogenesis of lipoid nephrosis: a disorder of T-cell function. Lancet, 2, 556-560.

Shapiro, S. (1974). Allopurinol and bone marrow depression. Lancet, 2, 412 .

Sharon, E., Kaplan, D., and Diamond, H. S. (1973). Exacerbation of lupus erythematosus after withdrawal of azathioprine therapy. New Engl. J. Med., 288, 122-124.

Sharpstone, P., Ogg, C. S., and Cameron, J. S. (1969). Nephrotic syndrome due to primary renal disease in adults. II. A controlled trial of prednisolone and azathioprine. Brit. med. J., 2, 535-539.

Sheil, A. G. R., Kelly, G. E., Mears, D., May, J., Johnson, J. R., Ibels, L. S., and Stewart, J. H. (1973). Antilymphocyte globulin in patients with renal allografts from cadaveric donors: late results of a controlled trial. Lancet, 2, 227-228.

Simmons, R. L., Kjellstrand, C. H., and Najarian, J. S. (1972). The kidney, Section 2: Technique, complications and results. In Transplantation, edited by J. S. Najarian, and R. L. Simmons. Lea and Febiger, Philadelphia.

Smithers, D. W., and Field, E. O. (1969). Immunosuppression and cancer. Lancet, 1, 672 .

Snaith, M. L., Holt, J. M., Oliver, D. O., Dunnill, M. S., Halley, W., and Stephenson, A. C. (1973). Treatment of patients with systemic lupus erythematosus including nephritis with Chlorambucil. Brit. med. J., 2, 197-201.

Solberg, C. O., Meuwissen, H. J., Needham, R. N., Good, R. A., and Matsen, J. M. (1971). Infectious complications in bone marrow transplant patients. Brit. med. J., 1, 18-23.

Sorrell, T. A., Forbes, I. J., Burness, F. R., and Rischbieth, R. H. C. (1971). Depression of immunological function in patients treated with phenytoin sodium (sodium diphenylhydantoin). Lancet, 2, 1233-1235.

Spencer, E. S., and Andersen, H. K. (1970). Clinically evident, nonterminal infections with herpesviruses and the wart virus in immunosuppressed renal allograft recipients. Brit. med. J., 3,
251-254.

Staples, P. J., Gerding, D. N., Decker, J. L., and Gordon, R. S., Jr. (1974). Incidence of infection in systemic lupus erythematosus. Arthr. and Rheum., 17, 1-10.

Starzl, T. E. (1964). Experience in Renal Transplantation. Saunders, Philadelphia.

Starzl, T. E., Groth, C. G., Putnam, C. W., Corman, J., Halgrimson, C. G., Penn, I., Husberg, B., Gustafsson, A., Cascardo, S., Geis, P., and Iwatsuki, S. (1973). Cyclophosphamide for clinical renal and hepatic transplantation. Trans. Proc., 5, 511-516.

Starzl,T. E., Halgrimson, C. G., Penn, I., Martineau, G., Schroter, G., Amemiya, H., Putman, C. W., and Groth, C. G. (1971). Cyclophosphamide and human organ transplantation. Lancet, 2, 70-74.

Steinberg, A. D., Kaltreider, H. B., Staples, P. J., Goetzl, E. J., Talal, N., and Decker, J. L. (1971). Cyclophosphamide in lupus nephritis: a controlled trial. Ann. intern. Med., 75, 165-171.

Steinberg, A. D., Plotz, P. H., Wolff, S. M., Wong, V. G., Agus, S. G., and Decker, J. L. (1972). Cytotoxic drugs in treatment of nonmalignant diseases. Ann. intern. Med., 76, 619-642.

Strauch, B., Andrews, L-L., Siegel, N., and Miller, G. (1974). Oropharyngeal excretion of Epstein-Barr virus by renal transplant recipients and other patients treated with immunosuppressive drugs. Lancet, 1, 234-237.

Swanson, M. A., and Schwartz, R. S. (1967). Immunosuppressive therapy: the relation between clinical response and immunologic competence. New Engl. J. Med., 277, 163-170.

Sztejnbok, M., Stewart, A., Diamond, H., and Kaplan, D. (1971). Azathioprine in the treatment of systemic lupus erythematosus: a controlled study. Arthr. and Rheum., 14, 639-645.

Tallent, M. B., Simmons, R. L., and Najarian, J. S. (1970). Birth defects in child of male recipient of kidney transplant. (Letter). J. Amer. med. Ass., 211, 1854-1855.

Tannenbaum, H., and Schur, P. (1974). Development of reticulum cell sarcoma during cyclophosphamide therapy. Arthr. and Rheum., 17, 15-18.

Thiersch, J. B. (1962). Effect of 6-(1'-methyl-4'nitro-5'imidazolyl) mercaptopurine and 2-amino-6-(1'-methyl-4'-nitro-5'-imidazolyl)-mercaptopurine on the rat litter in utero. J. Reprod. Fertil., 4, 297-312.

Thomas, L. (1959). In discussion of Medawar, P. B. Reactions to homologous tissue antigens in relation to hypersensitivity. In Cellular and Humoral Aspects of the Hypersensitive States, edited by $\mathrm{H}$. S. Lawrence, pp. 529-532. Hoeber, New York.

Toledo, T. M., Harper, R. C., and Moser, R. H. (1971). Fetal effects during cyclophosphamide and irradiation therapy. Ann. intern. Med., 74, 87-91.

Uldall, P. R., Kerr, D. N. S., and Tacchi, D. (1972). Sterility and cyclophosphamide. Lancet. 1, 693-694.

Walder, B. K., Robertson, M. R., and Jeremy, D. (1971). Skin cancer and immunosuppression. Lancet, 2, 1282-1283.

Walker, S. E., and Bole, G. G., Jr. (1973). Augmented incidence of neoplasia in NZB/NZW mice treated with long term cyclophosphamide. J. Lab. clin. Med., 82, 619-633.

Wall, R. L., and Clausen, K. P. (1975). Carcinoma of the urinary bladder in patients receiving cyclophosphamide. New Engl. J. Med., 293, 271-273.

Warne, G. L., Fairley, K. F., Hobbs, J. B., and Martin, F. I. R. (1973). Cyclophosphamide-induced ovarian failure. New Engl.J. Med., 289, 1159-1162.

West, C. D. (1972). Cyclophosphamide in renal disease. Presented to the International Workshop on Immunosuppressive Therapy. "Risk Benefit Assessment". Hotel Americana, New York. June, 1972.

Wilson, W. E. C., Kirkpatrick, C. H., and Talmage, D. W. (1965). Suppression of immunologic responsiveness in uremia. Ann. intern. Med., 62, 1-14.

World Health Organization (1972). Memorandum. A survey of nutritional-immunological interactions. Bull. Wld Hlth Org., 46, 537-546.

Worth, P. H. L. (1971). Cyclophosphamide and the bladder. Brit. med. J., 3, 182.

Young, R. C., Bennett, J. E., Vogel, C. L., Carbone, P. P., and DeVita, V. T. (1970). Aspergillosis: the spectrum of the disease in 98 patients. Medicine (Baltimore), 49, 147-173.

ZuRhein. G. M., and Varakis, J. (1974). Progressive multifocal leukoencephalopathy in a renal allograft recipient. (Letter). New Engl. J. Med., 291, 798. 